\title{
Enhanced endothelial cell functions on rosette nanotube-coated titanium vascular stents
}

\author{
Eli Fine' \\ Lijie Zhang' \\ Hicham Fenniri ${ }^{2}$ \\ Thomas J Webster' \\ 'Department of Engineering, \\ Brown University, Providence, \\ RI, USA; ${ }^{2}$ National Institute for \\ Nanotechnology and Department \\ of Chemistry, University of Alberta, \\ Edmonton, $A B$, Canada
}

Correspondence: Thomas JWebster Divisions of Engineering and Orthopedics, Brown University, 182 Hope Street, Providence, RI 02912, USA

Tel + | 40| 8632318

Fax + I 40I 8639107

Email thomas_webster@brown.edu

Hicham Fenniri

National Institute for Nanotechnology and Department of Chemistry,

University of Alberta, I | 42 |

Saskatchewan Drive,

Edmonton, AB T6G 2M9, Canada

Tel + I $78064 \mid 1750$

Fax $+|78064| 160 \mid$

Email hicham.fenniri@ualberta.ca

\begin{abstract}
One of the main problems with current vascular stents is a lack of endothelial cell interactions, which if sufficient, would create a uniform healthy endothelium masking the underlying foreign metal from inflammatory cell interference. Moreover, if endothelial cells from the arterial wall do not adhere to the stent, the stent can become loose and dislodge. Therefore, the objective of this in vitro study was to design a novel biomimetic nanostructured coating (that does not contain drugs) on conventional vascular stent materials (specifically, titanium) for improving vascular stent applications. Rosette nanotubes (RNTs) are a new class of biomimetic nanotubes that self-assemble from DNA base analogs and have been shown in previous studies to sufficiently coat titanium and enhance osteoblast cell functions. RNTs have many desirable properties for use as vascular stent coatings including spontaneous self-assembly in body fluids, tailorable surface chemistry for specific implant applications, and nanoscale dimensions similar to those of the natural vascular extracellular matrix. Importantly, the results of this study provided the first evidence that RNTs functionalized with lysine (RNT-K), even at low concentrations, significantly increase endothelial cell density over uncoated titanium. Specifically, $0.01 \mathrm{mg} / \mathrm{mL}$ RNT-K coated titanium increased endothelial cell density by $37 \%$ and $52 \%$ compared to uncoated titanium after $4 \mathrm{~h}$ and three days, respectively. The excellent cytocompatibility properties of RNTs (as demonstrated here for the first time for endothelial cells) suggest the need for the further exploration of these novel nanostructured materials for vascular stent applications.
\end{abstract}

Keywords: stents, nanotechnology, self-assembly, rosette nanotubes, endothelial cells, titanium

\section{Introduction}

Vascular stents are predominantly metal structures inserted into partially clogged arteries to promote normal blood flow and prevent myocardial infarctions. There is an enormous market for vascular stents with \$918 million in US sales in 2005 alone. ${ }^{1}$ The constant contact of vascular stents with blood has been the source of several unresolved efficacy issues. ${ }^{2,3}$ For example, conventional bare metal stents often trigger an inflammatory response leading to scar tissue formation, known as restenosis, which constricts blood flow defeating the original purpose of the stent. ${ }^{2}$ Drug-eluting stents counteract such events by releasing immunosuppressants, however, these immunosuppressants can also suppress desirable endothelial cell growth and sometimes lead to late-stage thrombosis. ${ }^{3}$ For the above reasons, this study focused on the design, synthesis, and investigation of a new non-drug containing material called rosette nanotubes (RNTs) to coat titanium stent surfaces in order to enhance endothelial cell adhesion and proliferation.

RNTs are novel materials composed of DNA base analogs featuring the hydrogen bonding arrays of both guanine and cytosine, the $\mathrm{G}^{\wedge} \mathrm{C}$ motif. This module selfassembles spontaneously in aqueous solutions first into a rosette supermacrocycle 
maintained by 18 hydrogen bonds (Figures $1 \mathrm{~A}-\mathrm{B}$ ). Then the rosettes undergo self-organization via noncovalent stacking interactions to form helical nanotubes with an inner diameter of $11 \AA$ and lengths ranging from a few nanometers to several micrometers (Figure 1C). Such nanometer dimensions of RNTs mimic the dimensions of the natural components of tissues, such as collagen fibrils. Furthermore, the outside of the tubes can be functionalized to possess various peptides and amino acid side chains (eg, K, RGD [arginine-glycine-aspartic acid]) to interact with cells and stimulate specific tissue growth.

For orthopedic applications, previous studies have shown that various functionalized RNTs have attractive properties including remarkably improved osteoblast (bone-forming cell) functions when coated on traditional implant materials (such as titanium) or embedded in hydrogels. ${ }^{4-8}$ Promoted osteoblast functions have been attributed to the nanoscale biologically-inspired features and the rich lysine or peptide moieties of RNTs. In addition, RNTs have been investigated as novel injectable materials which solidify when heated to body temperatures. ${ }^{4-7}$ Of course as with any new nanotechnology-derived material, toxicity could be a concern. However, in a recent in vivo study, Journeay and colleagues reported that RNTs did not trigger severe inflammatory responses and had low pulmonary toxicity in vivo at $\mathrm{mg} / \mathrm{mL}$ concentrations (toxic concentrations above which RNTs have been shown to promote cell functions). ${ }^{9}$

For all of the above reasons, especially due to the promise of coating titanium with RNTs for orthopedic applications, this report focuses on endothelial cell functions on RNTcoated titanium with the aim of improving vascular stent performance.

\section{Materials and methods}

\section{Substrate preparation and characterization}

Titanium squares (Ti, $10 \times 10 \times 0.5 \mathrm{~mm}$, Alfa Aesar titanium foil, 99\% metal basis) and glass coverslips (Fisher Scientific, Pittsburgh, PA) were cleaned in acetone for $15 \mathrm{~min}$, sonicated for $15 \mathrm{~min}$, and rinsed three times with Millipore distilled/deionized water $\left(\mathrm{ddH}_{2} \mathrm{O}\right.$; Millipore, Billerica, $\left.\mathrm{MA}\right)$. They were then soaked, sonicated, and rinsed in $70 \%$ ethanol then in $\mathrm{ddH}_{2} \mathrm{O}$. The glass was etched $(1 \mathrm{M} \mathrm{NaOH}, 1 \mathrm{~h})$ and thoroughly rinsed in $\mathrm{ddH}_{2} \mathrm{O}$. The substrates were then placed in a drying oven overnight and autoclaved before the cell adhesion experiments.

The RNT-K (RNTs functionalized with lysine) were synthesized as previously reported, ${ }^{10}$ and the corresponding solutions were sterilized by filtration via a $0.22 \mu \mathrm{m}$ syringe filter. ${ }^{4}$ To confirm the formation of the RNTs, a sample $(0.01 \mathrm{mg} / \mathrm{mL})$ was imaged on a Philips, EM410 PW6008 transmission electron microscope (Philips, Amsterdam, The Netherlands). One day prior to seeding cells, the titanium substrate samples were placed in solutions of either $0.01 \mathrm{mg} /$ $\mathrm{mL}$ or $0.001 \mathrm{mg} / \mathrm{mL} \mathrm{RNT}-\mathrm{K}$ for $45 \mathrm{~min}$, then removed and left to dry overnight.

\section{Endothelial cell culture}

Rat aortic endothelial cells (RAEC; VEC Technologies, Rensselaer, NY) were cultured in MCDB-131 Complete medium (VEC Technologies) under standard cell culture conditions $\left(37{ }^{\circ} \mathrm{C}\right.$, humidified, $5 \% \mathrm{CO}_{2} / 95 \%$ air). Medium was replaced every other day.

\section{Endothelial cell adhesion experiment}

For the $4 \mathrm{~h}$ cell adhesion studies, a 12-well plate was prepared with three samples consisting of $0.01 \mathrm{mg} / \mathrm{mL}$
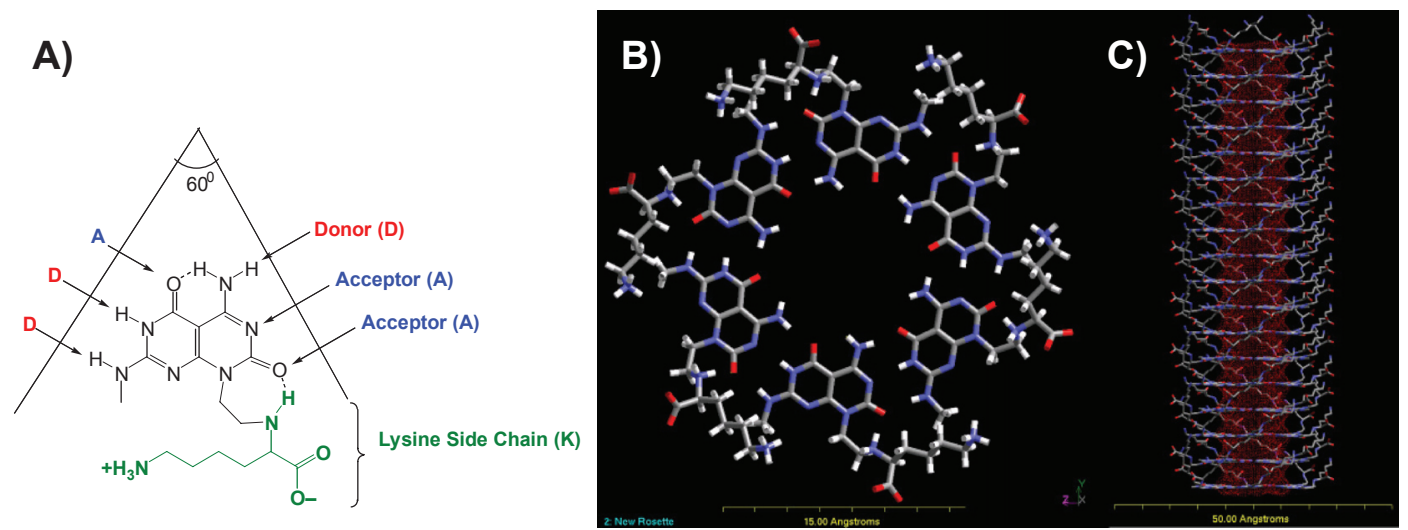

Figure I Schematic illustration of the self-assembly process of RNTs with a lysine (K) side chain (RNT-K) when placed in body fluids. A) The guanine-cytosine (G^C) motif with a lysine side chain; $\mathbf{B}$ ) a rosette supermacrocycle self-assembled from six $\mathrm{G}^{\wedge} \mathrm{C}$ motifs maintained by $18 \mathrm{H}$-bonds; and $\mathbf{C}$ ) the rosettes stack up to form a stable nanotube with a $\sim 3.5 \mathrm{~nm}$ outer and a $1 \mathrm{~A} \AA$ inner tube diameter. 
RNT-coated titanium, $0.001 \mathrm{mg} / \mathrm{mL}$ RNT-coated titanium, uncoated titanium, and a glass reference. Cells were seeded onto the substrates at a density of 3500 cells $/ \mathrm{cm}^{2}$ in $2 \mathrm{~mL}$ of MCDB-131 Complete Medium (Sigma-Aldrich, St. Louis, MO) and were incubated for $4 \mathrm{~h}$. The medium was then removed and the substrates were rinsed with phosphatebuffered saline $(\mathrm{PBS} ; 3 \times)$ to remove non-adherent cells. The adherent cells were then fixed with $10 \%$ formalin (Fisher Scientific) for $10 \mathrm{~min}$ and then rinsed with PBS $(3 \times)$. The cells were then fixed with $0.1 \%$ Triton $X-100$ (Sigma-Aldrich) for $5 \mathrm{~min}$. After sequential PBS rinsing, endothelial cells were stained with rhodamine-phalliodin (Molecular Probes, Carlsbad, CA) for $20 \mathrm{~min}$, rinsed with PBS $(2 \times)$, stained with DAPI (Invitrogen, Carlsbad, CA) for 5 min and rinsed with PBS. 4',6-Diamidino-2-phenylindole (DAPI) was chosen as a fluorescent dye since it stains the cell nucleus and can be used to count the number of cells present on opaque substrates. Rhodamine phalliodin was also chosen because it stains the F-actin filaments of endothelial cells and, thus, highlights cell morphology. After staining, endothelial cells were observed using a Zeiss Axiovert $200 \mathrm{M}$ fluorescence microscope (Carl Zeiss Microimaging Inc., Thornwood, NY) and five different areas of each sample were imaged. The cell density was determined by counting cells using Image Pro Analyzer (Media Cybernetics, Inc., Bethesda, MD).

\section{Endothelial cell proliferation experiment}

For the proliferation studies, three sets of substrates were seeded with endothelial cells at a density of 1000 cells $/ \mathrm{cm}^{2}$ and were placed in an incubator for 1,3 , and 5 days. The medium was changed every other day. After each time period, cells were stained and counted as described above.

\section{Statistical analysis}

All cellular experiments were run in triplicate and repeated at least three different times for each substrate. Numerical data were analyzed with a Student's $t$-test to make pairwise comparisons. Statistical significance was considered at $p<0.1$.

\section{Results and discussion RNT-K morphology}

Transmission electron microscopy images showed that the RNT-K used in the present study formed a dense network of long nanotubes each $\sim 3.5 \mathrm{~nm}$ in diameter and several hundred nanometers in length (Figure 2), consistent with earlier reports. ${ }^{4}$

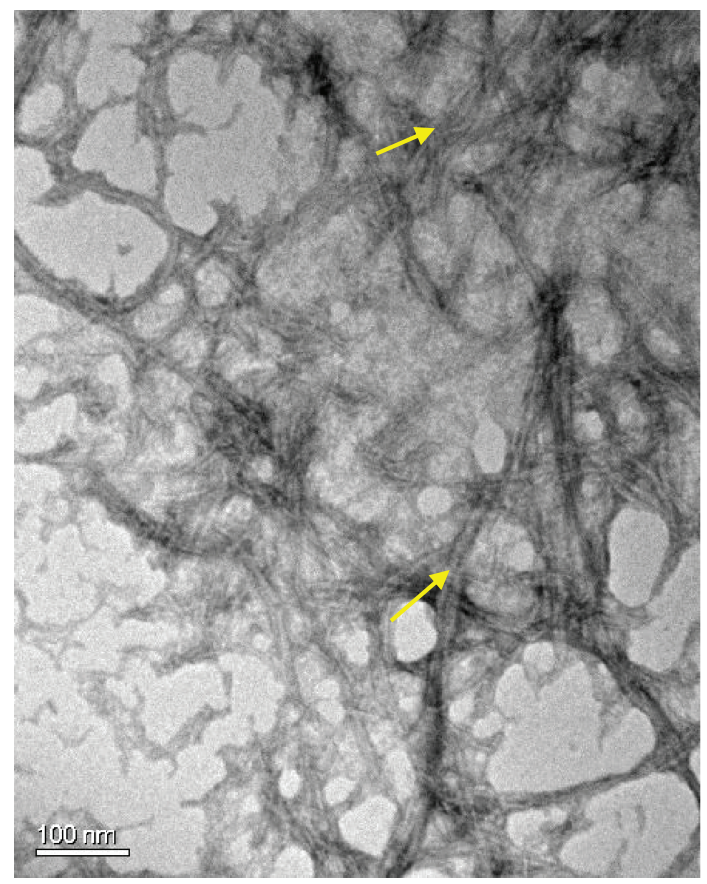

Figure 2 Transmission electron micrograph of RNT-K $(0.01 \mathrm{mg} / \mathrm{mL}$ in water). Arrows point to the RNTs.

Abbreviation: RNT-K, rosette nanotube-lysine side chain.

\section{Enhanced endothelial cell adhesion}

The $4 \mathrm{~h}$ adhesion study provided the first evidence that endothelial cells adhered at a higher density to RNT-coated titanium compared to uncoated titanium substrates. Specifically, the $0.01 \mathrm{mg} / \mathrm{mL}$ and $0.001 \mathrm{mg} / \mathrm{mL}$ RNT-K-coated titanium increased endothelial cell density by $37 \%$ and $22 \%$, respectively, over uncoated titanium (Figures 3 and 4).

One hypothesis concerning why increased endothelial cell adhesion was observed on RNT-coated compared to uncoated titanium is that the biomimetic features of the nanostructured RNTs favored endothelial adhesion whereas the uncoated titanium did not possess such biologically-inspired surface roughness. In addition, another study reported that poly-L-lysine-coated vascular stents significantly improved endothelial cell adhesion compared to uncoated controls perhaps due to the electrostatic or optimal initial protein interactions between poly-L-lysine and endothelial cells. ${ }^{11}$ Considering the rich lysine side chains and well controlled nanometer spatial distributions of such lysine side chains on RNTs, the surface chemistry of titanium was altered through RNT coatings to possibly promote greater endothelial cell attachment and spreading as shown in Figure 5.

\section{Endothelial cell proliferation}

Endothelial cell density increased on all substrates after 5 days of culture (Figure 6). More importantly, results of this 


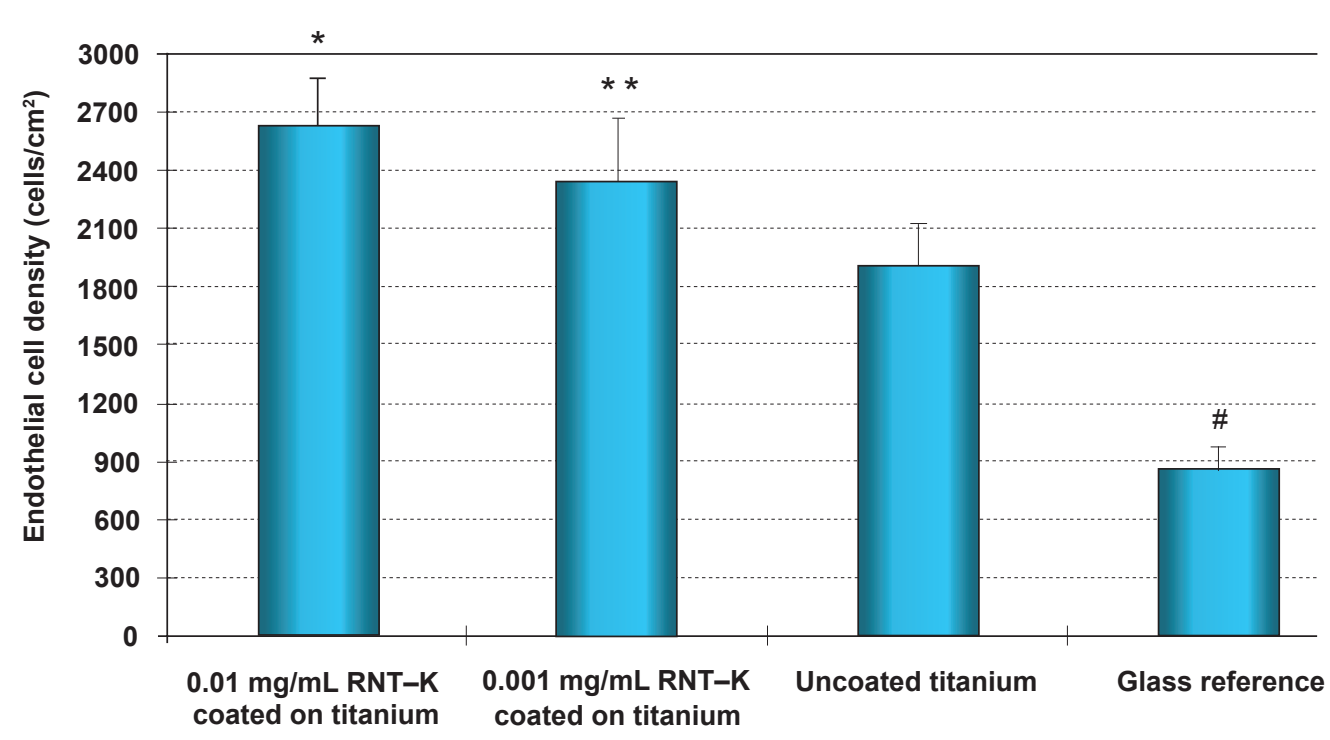

Figure 3 Enhanced endothelial cell adhesion on 0.01 and $0.001 \mathrm{mg} / \mathrm{mL}$ RNT-K coated on titanium after $4 \mathrm{~h}$ compared to uncoated titanium.

Notes: Data are mean values $\pm \mathrm{SEM} ; \mathrm{N}=3 .{ }^{*} \mathrm{p}<0.05 ;{ }^{* *} \mathrm{p}<0.1$ when compared to uncoated titanium; and ${ }^{*} \mathrm{p}<0.005$ when compared to all other substrates.

Abbreviations: RNT-K, rosette nanotube-lysine side chain; SEM, standard error of mean.

study provided the first evidence that RNT-K-coated titanium greatly improved endothelial cell functions compared to uncoated titanium (Figure 6). Specifically, the $0.01 \mathrm{mg}$ / $\mathrm{mL}$ and $0.001 \mathrm{mg} / \mathrm{mL} \mathrm{RNT-coated} \mathrm{titanium} \mathrm{increased} \mathrm{endo-}$ thelial cell density 52\% and 21\%, respectively, compared to uncoated titanium after three days of culture. In addition, endothelial cell densities were significantly higher on $0.01 \mathrm{mg} / \mathrm{mL}$ RNT $-\mathrm{K}$ coated titanium than on $0.001 \mathrm{mg} / \mathrm{mL}$ RNT-K-coated titanium after three days of culture. Such data supports the positive role that higher concentrations of RNTs can play in promoting endothelial cell coverage of vascular stents by (a) presenting more lysine side chains per unit of surface area, and/or by (b) more closely resembling the natural nanostructure of vascular tissue when coated on titanium.

By day 5, the RNT-coated titanium still had a higher average endothelial cell density, but the differences were no longer statistically significant (Figure 6). However, when analyzing endothelial cell numbers from day 1 to 5 , it was clear that endothelial cells reached confluency faster on the RNT-coated titanium than on the uncoated titanium. Furthermore, Figures 7 and 8 illustrate the difference in endothelial cell confluency on titanium when coated with RNTs.

In short, this study demonstrated for the first time improved endothelial cell density on RNT-coated titanium
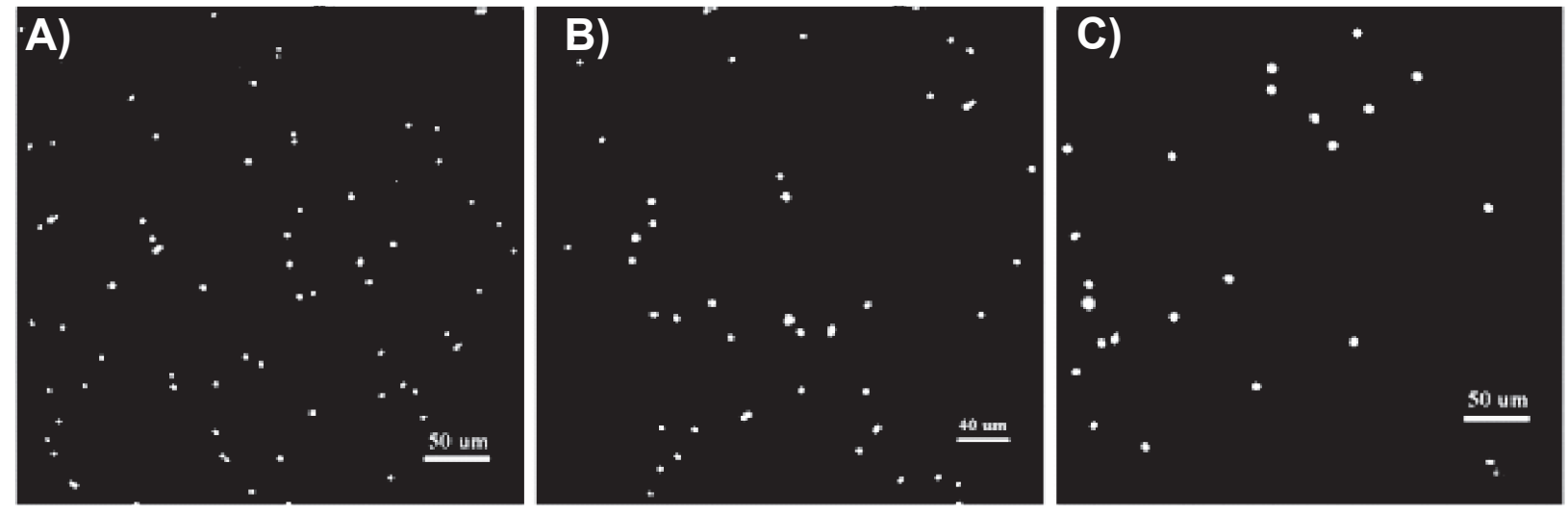

Figure 4 Fluorescence microscopy images of increased endothelial cell densities after $4 \mathrm{~h}$ on $\mathbf{A}$ ) $0.01 \mathrm{mg} / \mathrm{mL}$ RNT-K coated on titanium and B) $0.00 \mathrm{I} \mathrm{mg} / \mathrm{mL}$ RNT-K coated on titanium compared to C) uncoated titanium. Dots in the images represent DAPI-stained endothelial cell nuclei. Scale bars $=50 \mu \mathrm{m}$ (left), $40 \mu \mathrm{m}$ (middle), and $50 \mu \mathrm{m}$ (right) Abbreviations: DAPI, 4',6-diamidino-2-phenylindole; RNT-K, rosette nanotube-lysine side chain. 
$0.01 \mathrm{mg} / \mathrm{mL}$ RNT-K

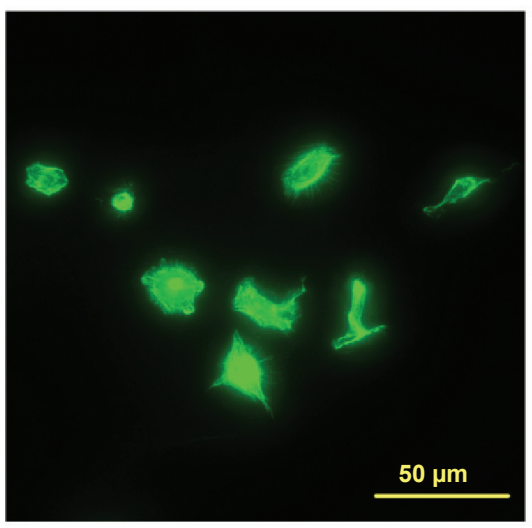

$0.001 \mathrm{mg} / \mathrm{mL}$ RNT-K

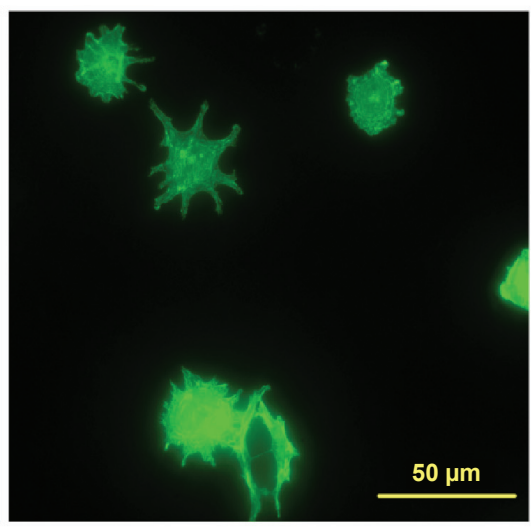

Uncoated titanium

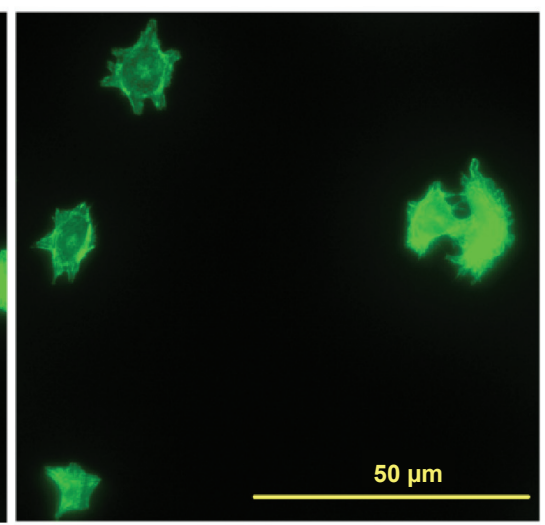

Figure 5 Fluorescence microscopy images of endothelial cells spreading on $0.01 \mathrm{mg} / \mathrm{mL}$ and $0.00 \mathrm{I} \mathrm{mg} / \mathrm{mL}$ RNT-K coated on titanium and uncoated titanium after 4 h. F-actin filaments were stained with rhodamine phalliodin.

Abbreviation: RNT-K, rosette nanotube-lysine side chain.

compared to uncoated titanium controls. Importantly, this was achieved without embedding or coating drugs on the titanium stent surface, rather, such positive data was obtained after simply soaking titanium in RNT-containing solutions for $45 \mathrm{~min}$. This study, thus, suggests the potential of using biomimetic RNTs as a quickly applied, efficient coating on titanium to improve cytocompatibility properties for vascular stent applications.

\section{Conclusions}

In summary, this initial investigation concerning endothelial cell functions on RNT-coated titanium stents yielded

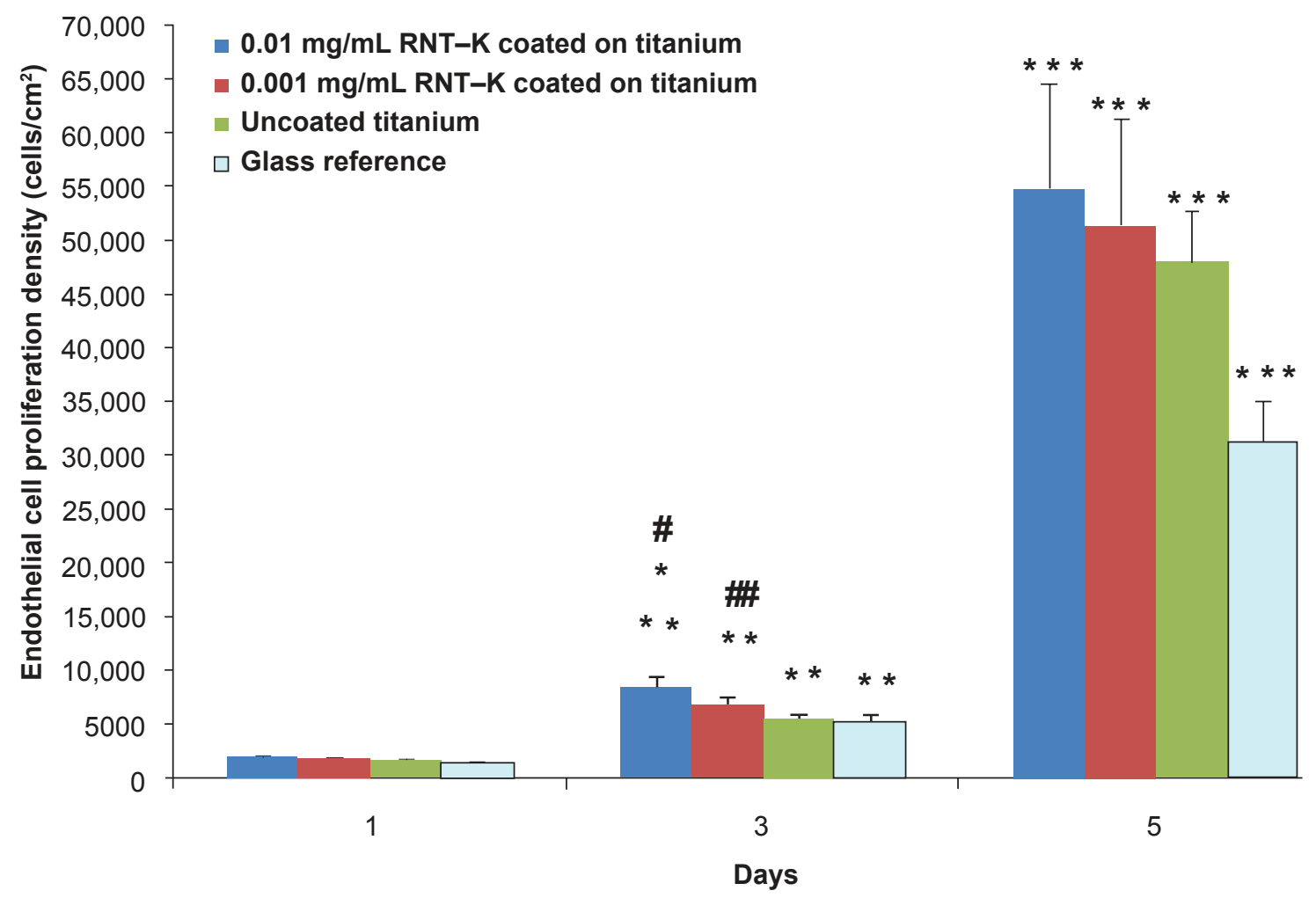

Figure 6 Enhanced endothelial cell density on RNT-K coated on titanium after 3 and 5 days.

Notes: Data are mean values $\pm \mathrm{SEM} ; \mathrm{N}=3 ;{ }^{\#} \mathrm{p}<0.01$ and ${ }^{\#} \mathrm{p}<0.05$ compared to uncoated titanium on day $3 ;{ }^{*} \mathrm{p}<0.05$ compared to $0.00 \mathrm{I} \mathrm{mg} / \mathrm{mL} \mathrm{RNT}-\mathrm{K}$ coated on titanium on day 3 ; ${ }^{* *} \mathrm{p}<0.00 \mathrm{I}$ compared to respective substrates on day I; and ${ }^{* * *} \mathrm{p}<0.00 \mathrm{I}$ compared to respective substrates on day 3 . Abbreviations: RNT-K, rosette nanotube-lysine side chain; SEM, standard error of mean. 


\section{$0.01 \mathrm{mg} / \mathrm{mL}$ RNT-K $\quad 0.001 \mathrm{mg} / \mathrm{mL}$ RNT-K Uncoated titanium}

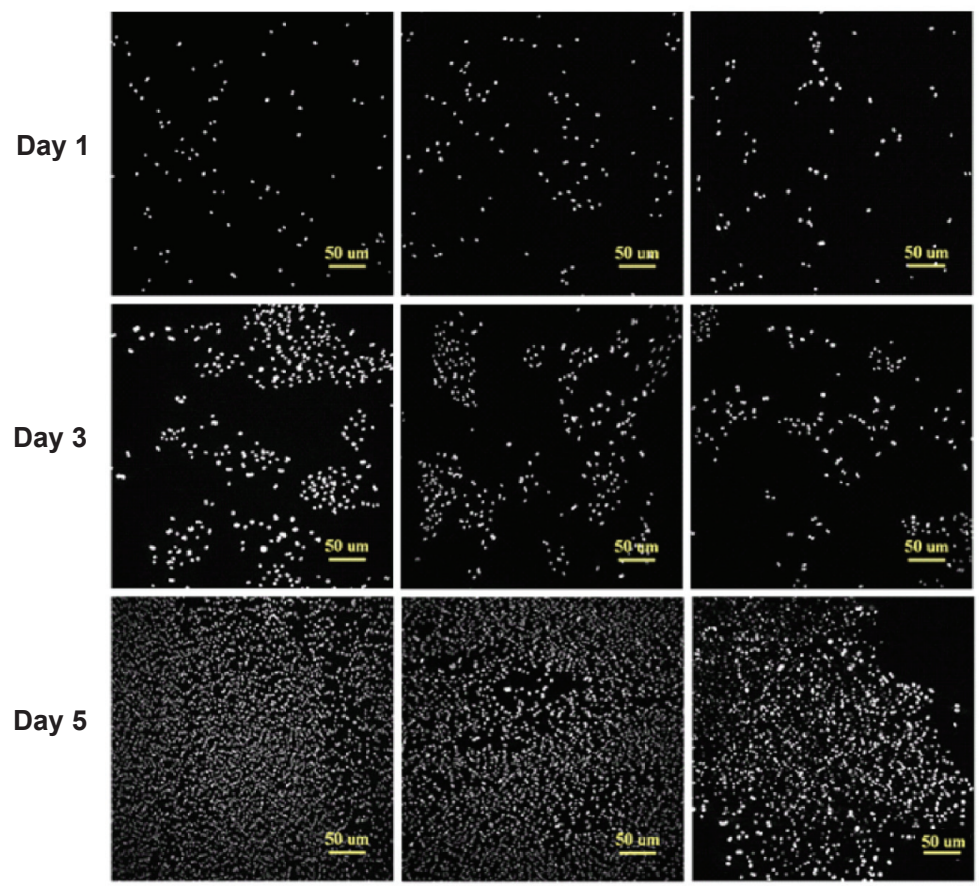

Figure 7 Fluorescence microscopy images of increased endothelial cell densities (DAPI stain) on $0.01 \mathrm{mg} / \mathrm{mL}$ and $0.00 \mathrm{I} \mathrm{mg/mL} \mathrm{RNT-K} \mathrm{coated} \mathrm{on} \mathrm{titanium} \mathrm{compared} \mathrm{to}$ uncoated titanium after I, 3 , and 5 days of culture.

Abbreviations: DAPI, 4',6-diamidino-2-phenylindole; RNT-K, rosette nanotube-lysine side chain.

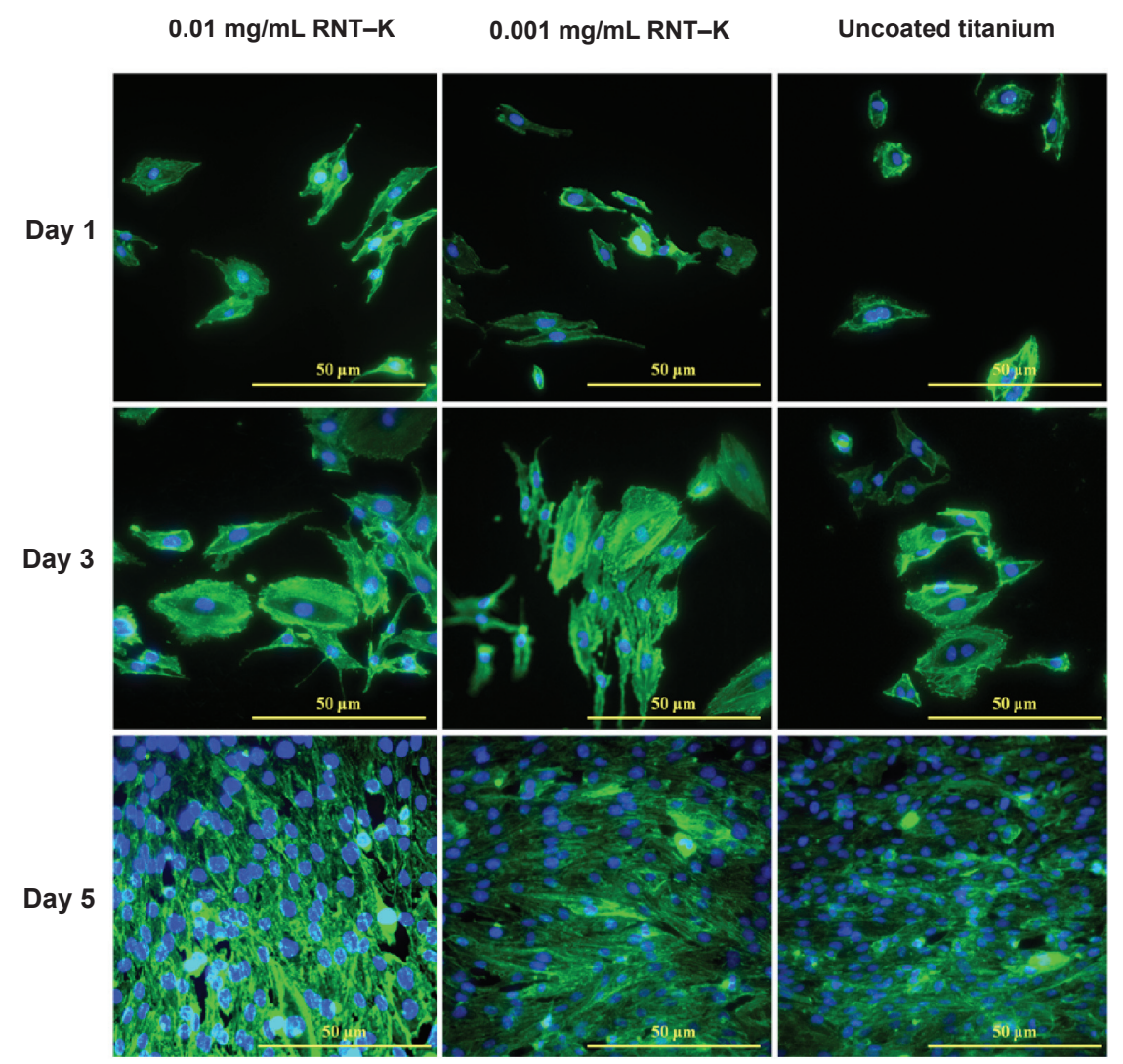

Figure 8 Fluorescence microscopy images of double-stained endothelial cells on $0.01 \mathrm{mg} / \mathrm{mL}$ and $0.00 \mathrm{I} \mathrm{mg/mL} \mathrm{RNT-K} \mathrm{coated} \mathrm{on} \mathrm{titanium} \mathrm{and} \mathrm{uncoated} \mathrm{titanium} \mathrm{after} \mathrm{I,} 3$, and 5 days of culture. F-actin filaments were stained by rhodamine phalliodin and cell nuclei were stained by DAPI.

Abbreviations: DAPI, 4',6-diamidino-2-phenylindole; RNT-K, rosette nanotube-lysine side chain. 
very positive results. Titanium coated with RNTs showed a significant concentration effect of increased endothelial cell density compared to uncoated titanium after $4 \mathrm{~h}$ and after three days. While further investigation is clearly needed, such as using dynamic flow rather than the static tests conducted here, the results of this study provided promise for the use of RNTs to improve vascular stent applications.

\section{Acknowledgments}

This work was supported by NIH Grant no. 1R21AG027521, Canada's National Research Council, NSERC, and the University of Alberta. The authors report no conflicts of interest in this work.

\section{References}

1. Medtechinsight.com. US Markets for Peripheral Vascular Stents, Irvine: Medtech Insight. Accessed Oct 23, 20 08. Available from: http://www. medtechinsight.com/ReportA250.html.

2. Hoffman GS, Weyand CM, editors. Inflammatory diseases of blood vessels. New York, NY: Marcel Dekker; 2002.

3. White CJ, editors. Drug-eluting stents: advanced applications for the management of coronary disease. New York: Taylor and Francis; 2005.
4. Chun AL, Moralez JG, Fenniri H, Webster TJ. Helical rosette nanotubes: a more effective orthopaedic implant material. Nanotechnology. 2004;15:S234-S239.

5. Chun AL, Moralez JG, Webster TJ, Fenniri H. Helical rosette nanotubes: a biomimetic coating for orthopedics. Biomaterials. 2005;26:7304-7309.

6. Zhang L, Ramsaywack S, Fenniri H, Webster TJ. Enhanced osteoblast adhesion on self-assembled nanostructured hydrogel scaffolds. Tissue Eng Part A. 2008;14(8):1353-1364.

7. Zhang L, Rakotondradany F, Myles AJ, Fenniri H, Webster TJ. Arginineglycine-aspartic acid modified rosette nanotube-hydrogel composites for bone tissue engineering. Biomaterials. 2009;30(7):1309-1320.

8. Zhang L, Rodriguez J, Myles AJ, Fenniri H, Webster TJ. Biologically inspired rosette nanotubes and nanocrystalline hydroxyapatite hydrogel nanocomposites as improved bone substitutes. Nanotechnology. 2009; In press.

9. Journeay WS, Suri SS, Moralez JG, Fenniri H, Singh B. Rosette nanotubes show low acute pulmonary toxicity in vivo. Int $J$ Nanomedicine. 2008;3(3):373-383.

10. Fenniri H, Mathiavanan P, Vidale KL, et al. Helical Rosette Nanotubes: Design, Self-Assembly, and Characterization. J Am Chem Soc. 2001;123(16):3854-3855.

11. Wang GX, Deng XY, Tang CJ, et al. The adhesive properties of endothelial cells on endovascular stent coated by substrates of poly-L-lysine and fibronectin. Artif Cells Blood Substit Immobil Biotechnol. 2006; 34(1):11-25. 
